\title{
Prestige Pricing Strategy as A Symbol of Social Class on Perfume Products
}

\author{
NYOMAN S. SUBAWA \\ Universitas Pendidikan Nasional, Denpasar, Bali 80225, Indonesia \\ Email correspondence: shribawa@gmail.com, shribawa@undiknas.ac.id
}

\begin{abstract}
Determination of the appropriate pricing strategy is essential in order to maintain and win the competition. This research examined the meaning of the application of the pricing strategy, especially prestige pricing for consumers who consume the product perfume in the city of Denpasar. The method used in this research is a qualitative method, by using descriptive analysis of qualitative and interpretative. The results showed that the first, the meaning of social class, that class was connected with the premium class perfume consumed by certain groups of people. Secondly, life style that is now for people using branded perfume is part of daily activities, and become part of the lifestyle. Because it was done patterned, repetitive, and in a certain period of time in accordance with the nature of the lifestyle itself. Third, are the value \& Psychological pricing, it was very specific in contrast to sales of other products in general. Producers to sellers maintain sales strategy accompanied with high price remain optimal service to attract or retain customers. Fourth, was the meaning of prestige, that the practice of buying branded perfume with an expensive price to increase or maintain the prestige of its users. Exchange of capital was very evident, buyers exchanging economic capital, social and cultural symbolic capital to achieve the sense of pride and prestige. In this research, the expected contribution is to interpret the application of prestige pricing strategy that so far only examined as part of the marketing strategy and consumer behavior.
\end{abstract}

Key words: Prestige Pricing, Social Class, Life Style, Perfume Product, Consumer Behavior.

\section{Strategi Penetapan Harga prestise sebagai Simbol Kelas Sosial pada Produk Parfum}

\begin{abstract}
Abstrak
Penentuan strategi harga yang tepat adalah penting untuk mempertahankan dan memenangkan persaingan. Penelitian ini meneliti makna penerapan strategi harga, terutama harga prestise bagi konsumen yang mengkonsumsi produk parfum di kota Denpasar. Metode yang digunakan dalam penelitian ini adalah metode kualitatif, dengan menggunakan analisis deskriptif kualitatif dan interpretatif. Hasil penelitian menunjukkan bahwa pertama, arti kelas sosial, kelas yang terhubung dengan parfum kelas premium yang dikonsumsi oleh kelompok orang tertentu. Kedua, gaya hidup yang sekarang bagi mereka yang menggunakan parfum bermerek adalah bagian dari kegiatan sehari-hari, dan menjadi bagian dari gaya hidup. Karena hal itu dilakukan bermotif, berulang-ulang, dan dalam jangka waktu tertentu sesuai dengan sifat dari gaya hidup itu sendiri. Ketiga, adalah nilai \& harga psikologis, itu sangat spesifik berbeda dengan penjualan produk lain pada umumnya. Produsen untuk penjual mempertahankan penjualan strategi disertai dengan harga tinggi tetap pelayanan yang optimal untuk menarik atau mempertahankan pelanggan. Keempat, adalah arti prestise, bahwa praktek membeli parfum bermerek dengan harga yang mahal untuk meningkatkan atau mempertahankan prestise penggunanya. Pertukaran modal sangat jelas, pembeli bertukar modal ekonomi, sosial dan modal simbolik budaya untuk mencapai rasa kebanggaan dan prestise. Dalam penelitian ini, kontribusi yang diharapkan adalah untuk menafsirkan penerapan strategi harga prestise yang sejauh ini hanya diperiksa sebagai bagian dari strategi pemasaran dan perilaku konsumen.
\end{abstract}

Kata kunci: Prestise Harga, Kelas Sosial, Gaya Hidup, Parfum Produk, Perilaku Konsumen. 


\section{INTRODUCTION}

Business competition in any kind of business today is highly competitive, which may have consequences for the company to find the right strategy to compete and win the competition. The company's ability to manage its resources both financial resources, human, technological excellence as well as production and marketing determine business success. But in this paper will focus on the marketing side that was one indication of the company's objectives, how the product can be marketed and consumed by consumers continuously and sustainably. In this context, it takes strategy as a guideline for deploying the mission and goals to be achieved by the company. Limitations in resources and the uncertainty of the strength of the broader market competition require the right strategy in marketing.

The implementation of a marketing strategy by companies can not be separated from the product strategy, promotion, place and price. The four strategies are interrelated and give due consideration to the mindset and behavior of consumers in determining product choice (Tjiptono, 2008). The phenomenon that occurs today is how to ensure you get more value paired with the consumption of other products. Value in question may be product differentiation, exclusive, service differentiation, image or differentiation in terms of pricing. Application of differentiation necessarily unique or something different, which can be highlighted, interesting, specific, and have value for customers. It is a competitive advantage for the company. Price is something that is used as a measure or indication of the value and the benefits of consumers.

Prestige pricing strategy, is one of the strategies in pricing the high price level. It is done as a form of imaging that the value of the products offered are value and high quality (Tjiptono, 2008). It means that psychologically, the high price of a product reflects the level of social class of consumers is high. The consumer purchase decision is influenced by the characteristics of the consumers themselves. Referring to the theory of consumer behavior Kotler \& Armstrong (1994) that the factors behind the consumer to make a purchase are factor of culture, social, personal, and psychological. Similarly, when talking about a factor of social class, which is part of the consumer culture. Social Class has common characteristics in members of the class, both the similarities in values, interests and behaviors. Social class can be shown through consumer behavior in choosing the type, quality, quantity, type and brand of product consumed. One of the products that were examined in this study is the product of perfume, which has a variety of brand, price, aroma, excellence appearance (packaging), and others. Perfume products in addition to indicate the social class of consumers, nor is it the primary product and the requirements that must be met, but it is part of life style, which is always dynamic and influenced by environmental factors as well as personal existence in the quality of the association of the wearer. This research was conducted not in spite of the uniqueness of the product sales of the perfume itself, especially perfumes belonging to the premium class, that the buyer actually interested steeper prices offered by producers. In contrast to the pattern of consumption of other products, in general, buyers tend to seek the lowest possible price, especially consumers who are sensitive to price. From exposure, the researchers are interested in studying more about what the meaning of the application of prestige pricing strategy for consumers on perfume products. Contributions desirable in this research is to give meaning to the application of prestige pricing strategy that had been in various studies, more scrutiny as a marketing strategy and consumer behavior analysis.

\section{LITERATURE REVIEW}

\section{Theoretical studies}

There are previous studies that provided the inspiration for this study, the research done Hinterhuber \& Liozu (2014) states that innovation contributes the most powerful price and as a source of corporate competitive advantage and customer satisfaction. Pricing a product has several objectives which are for profit, increased sales volume, preventing the entry of competitors, maintain customer loyalty, oriented imaging/prestige and other purposes. Pricing strategies applied by the company will greatly affect the control of the target market in order to win the competition. A second study conducted Spann, et.al (2015), where the research results show that there has been a practice of domination of the market price, the application of dynamic pricing strategy in 


\section{JURNAL BISNIS \& MANAJEMEN}

ISSN 1412 - 3681

the growth phase and the introduction of products that are usually performed at the launch of new products. Spann connects the practice with the theory of price skimming or penetration rates. Skimming price is higher pricing for new products or innovative products during the introductory stage, then lowered the price when fierce competition going on. While penetration rates are lower pricing for new products in order to obtain a high enough volume of sales in a relatively short time. Other research is Beracha and Seiler (2014), which shows the empirical findings that buyers and sellers of housing has significantly significance to the price of new homes than existing homes. Three studies above provide inspiration to researchers, which of the three studies that no one has specifically examined and uncover the Prestige pricing strategy associated with social class and other meanings in the international branded perfumes products in Denpasar.

Related to the topic of this research, it is necessary to set out some concepts are as follows. Prestige pricing strategy, is high pricing strategy of the product offered to consumers (Tjiptono, 2008). This policy of the company, so that the product continues to reflect and perceived by consumers as a brand and high quality products. This will provide a high prestige and imaging for consumers who consume them.

Social class, can be defined as a permanent group whose members have values, interests, and the same behavior (Kotler \& Armstrong, 1994). Social class is not determined by a combination of occupation, income, education, health and others. By knowing the social class of customers it can be seen buying behavior does. Another opinion, Hawkins et.al. (2001) Social Class declare a level of society into different groups and form a homogeneous group linked to attitudes, values and lifestyles.

The theory used in this study is the Consumer Behavior Theory and Theory of Social Practice. Hawkins et.al. (2001) says that consumer behavior is based on the purchase decision process problem recognition, information search, alternative evaluation and selection, purchase and process postpurchase. External and internal influences consumer to be considered in determining the self-concept and lifestyle. It is used to examine the phenomenon of consumer choice in the decision to consume products associated social class perfume. Second, is the theory of social practice initiated by Pierre - Felix Bourdieu (in Haryatmoko, 2003), said the capital has a role in social relations, as a system of exchange of goods in the form of material and symbol. Then, the social structure, covering the realm of the economic capital, cultural, social and symbolic. Briefly Theory of Social Practice, namely (habitus $x$ capital) + domain $=$ practice.

Framework in this study can be described as follows:

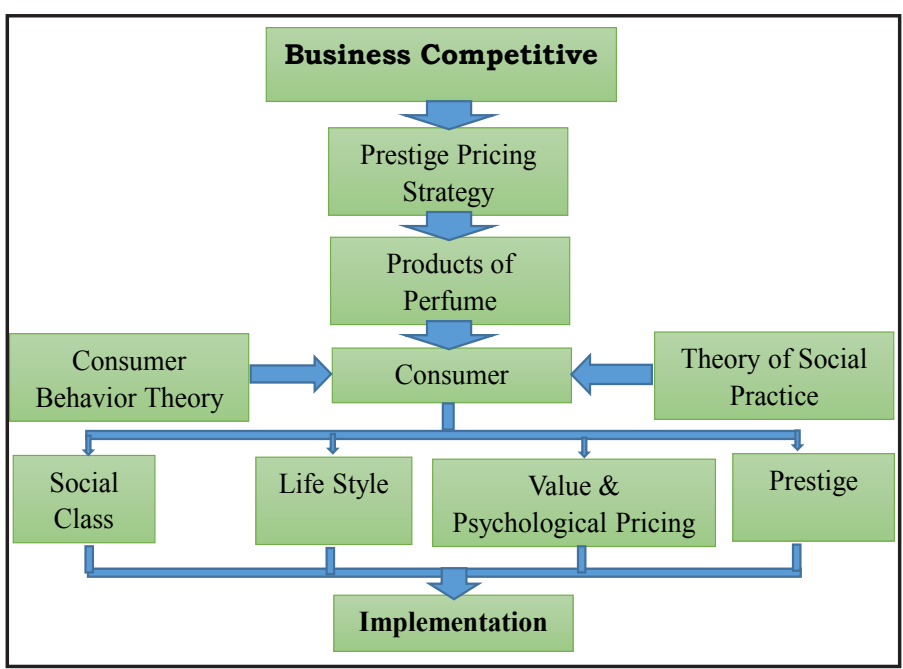

Source: Author

Figure 1 Framework Research

Business competition is currently very competitive and of course companies must find a strategy in order to survive and dominate the market. One that is discussed in this study is related to the implementation of pricing strategies, particularly prestige pricing on perfume products. Dissecting the problems with the theory of Consumer Behavior and Social Practice theory hereinafter described on Social Class, Life Style, Value and Prestige implemented consumers to perfume products.

\section{METHOD}

This research was uncovering and addressing, namely the application of prestige pricing strategy as a symbol of social class consumers in perfume products in Denpasar. This study used a qualitative method, which was analyzed with descriptive qualitative and interpretative. Denpasar city as a locus of research was caused by people of diverse 
characteristics, including ethnicity, income level and relatively high purchasing power, lifestyle patterns metropolis, its people were fashionable, and more. Qualitative data was used as the primary data, gathered through informants. Secondary data was also used as supporting data. Informant as the source of the data in this study amounted to five informants, which included consumers, retailers and distributors managers perfume products. Selection of informants was done by purposive sampling and data were collected through observation, interview and documentation.

\section{RESULT AND DISCUSSION}

Pricing strategies, prestige pricing is high pricing by the company as the implementation of consumer perceptions of these products, that high prices show the best product quality. It gives prestige pricing strategy for its users and still maintain high prices so that consumers do not turn to other products. It was also applied to the perfume, which had a distinctive aroma, unique bottles, futuristic, interesting and show class. The application of high prices remain in place, although in certain moments are given special discounts to consumers, it was not too big, just as a sweetener, the figure is about five to ten percent of the product price, said one store manager brand of perfume. The data obtained by researchers through interviews and observations could be described and interpreted meaning for consumers when they consumed products perfume prestige pricing strategy as follows.

\section{Social Class}

Social class hierarchy reflects the level of public and homogeneous groups that have similarities in attitudes, understanding values, and lifestyle. Various social class groups are formed based on education, employment, income, residence and others in line with the main purpose of social class. Observations show that consumers who consumed products of international branded perfumes were those earning above fifteen million, worked as a young executive, had no formal education in higher education and lived or own their own homes and stayed in the elite housing. It means that the consumer characteristic perfume products show a different social class, 'exclusive'. Consumers want something different, so by consuming the product can raise the sense of 'exclusive' which is a limited part of the community, has the features and characteristics of the social classes 'exclusive' (Subawa, in Erfiani, 2015).

Further proposed by Martin (2015) said that the social class reflects the identity of the individual in the social life of the community, which is still to be maintained in its class. For this reason, each individual would make efforts in order to always be able to maintain their social class and quality of the interaction. One of its efforts was to consume a classy perfume products (international brand). It can be interpreted that social class was connected with the premium class perfume consumed by certain groups of people. Analogy expressed by Bourdieu (Harker, 1990) is apt to describe the meaning, using three major qualitative categories, namely the sense of otherness to upscale, good will for middle-class culture, and choices need for the working class. Sense of distinction owned by the upper classes conducted by the form of loyalty to consume premium class perfume can demonstrate their social class as upper class society, socialite, or other designations. The reason that expression conveyed an informant who is loyal users, enthusiasts and observers of each of the international branded perfumes can refer the meaning of social class, as follows.

"Perfume branded in my opinion was something that could show if I am different from others, may equally wear perfume but check out what the brand?".

Similar to this, another informant who works as a power marketer of branded perfumes at a shopping center stated as follows.

"The perfume consumers which I sell is customer brand fanatic, they do not want to buy perfume that is not imported, if you buy a brand around it, even those up-date with new scents, new products are launched. They usually stop by the perfume counter and messaging products and have been informed if there is a new fragrance".

It can be analyzed if the informants above statement refers to the social class they are trying to maintain through the act of taking an international brand perfumes. Despite their tendency to switch from one brand to another brand, but the brand is still 


\section{JURNAL BISNIS \& MANAJEMEN}

ISSN 1412 - 3681

labeled import into their choice. "Fanatic brand" is the nickname of the right that can be given to this upscale community. Opinions Piliang (2004) further confirms how social class was strongly associated with consumption patterns, that "the tendency common to the formation of a symbol of social and cultural identity through clothing styles, car, or other production as symbolic communication and the meanings of social values has plagued the people of Indonesia in the last decade. Consumption is no longer defined solely as the traffic of cultural objects, but becomes a social stage, in which the social meanings in the fighting, a war in which the position of the members of the community involved. Consumer products is a medium for the formation of the personality, image, lifestyle, and social status differentiation way different.

Related to aspects of theoretical, social class actually very related to Theory of Social Practice, especially habitus that attitude, manner and style where the actor brought his own, such as attitude, body language, how to walk, and others (Jenkins, 2004). Habitus is interpreted as a habit to be practiced in the realm with the optimization of the four capital includes cultural, economic, social and symbolic. Meaning social class can also be explained by the theory of consumer behavior from Kotler \& Armstrong (1994) that people who consume branded perfumes based on personal factors, namely the concept of self and personality. The concept of self- constructed as the upper classes, fans of branded products, which later became part of his personality.

\section{Life Style}

Hawkins et.al. (2001), life style shows how life was done, in terms of activity, attitude, what is consumed, expectations, interest in something that will have an impact on the behavior of the purchasing decision and consumption. Even this study, perfume products consumed gave high expectations, both sides of scents constantly renewable, packaging diverse models, as well as brand/type offered was varied so that the purchasing behavior carried out repeatedly and part of daily life. Consumption showed the consumer's identity as a social class and the different communities.

Referring to the theory of consumer behavior, that consumption of repeatedly committed consumer is a response back for actions stimuli marketing company perfume products from several aspects, including product (packaging, scent, shape), aspects of the promotion (advertising star artist, endorsement), aspects of distribution (certain prestigious place), and aspects of the price (relatively high). This action is in response to consumer choice good choice for perfume products, brands selected, which will buy and the price indicates social class. In contrast to research conducted Danziger, et.al. , (2014) on how to price considerations as the choice of consumers to the retailer before shopping to the store. Research results show that consumers prefer retailers who offer low prices every day or offer to discount. Similarly, research by Giri and Sharma (2014) which states that manufacturers adopt the application of different pricing strategies for each retailer. It is done as a stimulus to retailers and consumers that the product turnover rate can run faster and consume process continues over time that becomes part of their lifestyle.

Direction of the times, consumers will seek and find patterns and something new that can provide more value and different from the others. When consuming products perfume, researchers discovered a phenomenon that consumers hunt for new products to add to the collection of perfume products so impressed varied in the use and consumption of perfumes. This is their lifestyle. This positive response by the perfume manufacturers who are always launching new products with a distinctive aroma and different. The discovery of raw materials and processing technologies perfume will create an exclusive product. Ryden (2015) said that technological developments will have an impact on lifestyle changes, and vice versa lifestyle changes will arise new ways to always use the technology. It means that the lifestyle is dynamic and evolving. Likewise with perfume products, evolving technologies will create new products that change lifestyle patterns of consumers. Various perfume with diverse formulations always offered to consumers, who are hungry for 'something new', and unwittingly been used as 'objects' by the manufacturer or capitalist. The phrase "markets are us" put forward Steger (2006) is apt to represent these conditions. Market of producers of perfume is the community itself, 
the manufacturer conducted a study of the needs of society according to age, profession and economic conditions. Once it is done product launches perfume, the capitalists which includes producers will strive mightily to instill awareness in the minds of consumers the importance of using perfume. In this case the premium class perfumes such as Channel, Jar, Bvlgari, Versace, Dolce \& Gabbana, Polo, Kenzo, Elizabeth Arden, Aigner and other brands.

Through the cultivation of awareness when using a branded perfume is part of the lifestyle classy. Branded terms (branded) defined by Quart (2008) as the behavior of those who are only willing to consume products of famous brands. When examined further, in fact they can be classified as "consumer society" that community "socially constructed" by capitalism in which everyone is conditioned to seek and find the meaning of life (only) through acts of consumption (Piliang, 2004). So unknowingly, this consumer society feel if using branded perfume is a necessity, and has become a habit in the practice of everyday life. If it is associated with the theory, then this condition can be explained by the theory of Practice Social, use perfume has become a habitus as a practical action that is not necessarily realized, which is practiced in the realm is the network of social relations by using capital utilization of economic, social, cultural, and symbolic.

\section{Psychological Value \& Pricing}

Kotler \& Armstrong (1994), value pricing, offering the right combination, product quality and good service at reasonable prices. The other hand, psychological pricing is a price adjustment for psychological impact for consumers. Thus, value and psychological pricing reflects the suitability of the product quality and prices offered to consumers as well as providing psychological impact for its users. That is the application of the appropriate price (high) to perfume products provide psychological meaning for the consumer, whose identity and pride when the product is used. When it is analyzed by the theory of social practice, there have been exchanges of economic capital to buy at high prices with the symbolic capital are consumers in the form of pride (the consumption of international brands and well-known), as a symbol of social class, classy and exclusive identity.
Fanaticism of the premium class perfumes carried by some people indicate if the price is not a barrier for them. Based on the observations of researchers at the study site, is precisely the excessive discounts granted by the sales agent often raises questions in the minds of consumers. Then the perfume sellers prefer to give bonuses to their customers purchase. As stated by the informant perfume seller following.

"We rarely join the discount program contrived by the mall, let alone a discount up to fifty percent, or seventy five percent, then the customer even wondered why branded perfumes great discounts? Whether such products were not sold anymore? Or no scent or launching new products so long discounted products? These will cause a lot of customer inquiries. We usually give a bonus or gifts to the buyer. Consumers who buy large packaging products then given bonus miniature perfume or attractive cosmetic bag, deodorant, make-up equipment or calendar".

Interesting things submitted by the informant above was the strategy of maintaining high prices made in selling the perfume products. Although they sell perfumes in shopping centers that hold a program granting a discount, but the sellers still survive to not provide a discount for the sake of sustaining status upscale perfume, which of course can provide a psychological effect for the buyer. When examined more in depth the seller actually building and maintaining the imaging product that is as classy perfume products. Value psychological pricing is closely related to the concept of imaging, which was a strategy. Piliang (2004) suggested that imaging was the main strategy in the capitalist relations of production and consumption, that it contains concepts, ideas, themes, or ideas that are packaged and grafted into a kind of public memory (public memory). Further stated that the image is an instrument to control the life of the soul (inner life), establish and organize external behavior of each person it affects. Image form the basis for selecting, in determining good or bad, true or false, useful or useless on an object.

On this strategy, international sales of branded perfumes carried through with a high standard pricing with optimum service so buyers do not feel it as a burden. Consumers feel the expected gain self-image, such as image as a well-established professional 
workers with income and able to maintain good performance through the use of the branded perfume. Producers also get a perfume - image as a manufacturer of top-class perfume. Observing that meaning can be expressed if the achievement was not only a symbolic capital acquired by the seller but also the buyer. Through the high economic capital employed, they can achieve symbolic capital.

\section{Prestige}

Lee (2006), objects or products have a symbolic function as a sign of social (prestige, status and social position relative). It means that the consumption of perfumes in addition to functioning product and benefit as fragrances, body, as well as to increase the prestige, pride and increased self-confidence, although in fact is not an excuse and the main goal in consuming perfume. The study of social practice theory also suggests that economic capital through money paid by the consumer, gain and interchangeable with social capital, namely through social relations, strengthen relationships in the community and social class groups of consumers. Economic capital is also interchangeable with symbolic capital, in the form of a symbol of prestige and pride gained when consuming the product. This is corroborated by the opinion of Bourdieu (Harker et.al., 1990) that are culturally, prestige, status, and authority was referred to as symbolic capital. In this connection, the capital also are "exchangeable". Exchange the greatest place on the symbolic capital with other capital, through the exchange of three capital as well as to produce symbolic capital, in the form of prestige in economic life, especially in the practice of buying international brand perfumes.

Wagner \& McLaughlin (2015) discloses that habitus is Bourdieu's theory of practice habits of everyday life by using four capital, namely capital economic, social, cultural and symbolic. In this study the use of the perfume is a daily practice, the custom of consumers as a form of identity and their behavior. By using economic capital, in the form of money and cultural capital in the form of knowledge about the quality, brand and perfume to achieve social capital in the form of social networking, community, class and social relations and achieve symbolic capital through symbols as consumers classy, labeling as people who pay attention to appearance and a sense of pride in community and social class bears. Indeed consumer economic capital incurred relatively high, considering the price of perfume is consumed is high or premium.

Empirically, the launch of new products is typically done by observing the market, the competitors, the macro environment, the strength of the company and others to determine the most appropriate strategies, especially strategies in pricing. This is done in order to maintain and increase the market share of products and target market segments. But the prestige pricing strategy is not so. This strategy is determined to maintain the high price level that aims and targets for middle and upper segments. Price shows the quality of products and services, related to prestige be declared if by referring to the high price fixing actual producers, power marketers until the middle maintain its prestige as a producer of premium class perfume.

\section{CONCLUSION}

Referring to the exposure of the preliminary determination of the formulation of the problem, and a description of the discussion about the meaning of strategy implementation prestige pricing for consumers, while taking perfume products are: first, the meaning of social class that social class is connected with the perfume class premium consumed by certain community groups, social classes trying maintained by always buy perfume despite the relatively high price. Secondly, the meaning of life style that is now for people using branded perfumes are a necessity, and has become a habit in the practice of everyday life, so it has become part of the lifestyle. Branded perfume fans is classified as a consumer society, the people who are socially consumed by the capitalists. They are the markets of the perfume manufacturers. Third, the meaning of value and psychological pricing, which the manufacturer, to the seller retains a high price sales strategy accompanied optimal service. There is considerable concern within the seller if perfume is sold at a low price, then the buyer actually questioned and reduces exclusive impression of the perfume itself. So that in selling the marketing more often give bonuses or prizes to attract customers. The fourth is the meaning of prestige, that the practice of buying branded perfume with an expensive price to increase or maintain the prestige of its users. They 
exchange economic capital, social and cultural rights to achieve the symbolic capital that is prestige. Given the limitations of the researcher, then the meaning would be excavated and studied further, in order to generate outputs corresponding theoretical concepts or principles of scientific knowledge, especially in developing marketing management and consumer behavior. The study recommended can be done by other researchers associated factors considered marketers in applying prestige pricing strategy and factors into the consumer appeal as well as its impacts.

\section{REFERENCES}

Beracha, Eli \& Seiler, Michael J. (2014). "The Effect of Listing Price Strategy on Transaction Selling Prices". The Journal of Real Estate Finance and Economics. Volume 49. Issue 2. Page $237-255$.

Danziger, Shai., Hadar, Liat \& Morwitz, Vicki G. (2014). "Retailer Pricing Strategy and Consumer Choice under Price Uncertainty". Journal of Consumer Research. Volume 41, Issue 3. 1 October. Page 761 - 774. Retrieved: http://jcr.oxfordjournals.org

Giri, B.C., \& Sharma, S. (2014). “Manufacturer's Pricing Strategy in a Two-Level Supply Chain with Competing Retailers and Advertising Cost Dependent Demand". Economic Modelling. Volume 38. Page $102-111$. Rettieved: http://www.sciencedirect.com

Harker, Richard., Mahar, Cheen. \& Wilkes, Chris. (1990). (Habitus $\times$ Modal) + Ranah = Praktik: Pengantar Paling Komprehensif kepada Pemikiran Pierre Bourdieu (Penerjemah: Pipit Mizer) Yogyakarta: Jalasutra.

Haryatmoko. (2003). “Menyingkap Kepalsuan Budaya Penguasa: Landasan Teoritis Gerakan Sosial Menurut Pierre Bourdieu". Basis: Menembus Fakta. Edisi Nov-Des. No. 11-12. Jakarta. PT. Masif Indonesia.

Hawkins, Del I., Best, Roger J., \& Coney, Kenneth A. (2001). Consumer Behavior: Building
Marketing Strategy. Edition 8th. International Edition ISBN 0-07-118039-7. Published by McGraw-Hill Companies, Inc.

Hinterhuber, Andreas \& Liozu, Stephan M. (2014). "Is Innovation in Pricing Your Next Source of Competitive Advantage?". Journal Business Horizons. Volume 57. Issue 3. MayJune. Page 413-423. Retrieved: http://www. sciencedirect.com Kelly School of Business, Indiana University. Published by Elsevier.

Jenkins, Richard. (2004). Membaca Pikiran Pierre Bourdieu (Penerjemah Nurhadi). Yogyakarta: Kreasi Wacana.

Kotler, Philip. \& Armstrong, Gary. (1994). Principles of Marketing. Sixth Edition. Prentice Hall International Editions.

Lee, Martyn J. (2006). Budaya Konsumen Terlahir Kembali Arah Baru Modernitas dalam Kajian Modal Konsumsi dan Kebudayaan. Yogyakarta: Kreasi Wacana.

Martin, Georgianna L. (2015). "Always in My Face: An Exploration of Social Class Consciousness, Salience, and Values". Journal of College Student Development. Volume 56. Number 5. July. Pp. 471-487. Retrieved: http://muse. jhu.edu

Piliang, Yasraf Amir. (2004). Dunia Yang Dilipat Tamasya Melampaui Batas-batas Kebudayaan. Bandung: PT. Jalasutra.

Quart, Alissa. (2008). Belanja Sampai Mati. Yogyakarta : Resist Book.

Ryden, Lars. (2015). "Technological Development and Lifestyle Changes". Sustainable Development, Knowledge Society and Smart Future Manufacturing Technologies. World Sustainable Series. ISBN 978-3-31914883-0 Springer International Publishing. Page 113-124.

Spann, Martin. Fischer, Marc. \& Tellis, Gerard J. (2015). "Skimming or Penetration ? Strategic 
Dynamic Pricing for New Products". Journal Marketing Science. Volume 34. Issue 2. March. Page 235-249. Retrieved: http:// www.dl.acm.org Institute for Operations Research and The Management Sciences (INFORMS), Linthicum, Maryland, USA.

Steger, Manfred B. (2006). Globalisme: Bangkitnya Ideologi Pasar (Penerjemah: Heru Prasetia). Yogyakarta: Lafadi Pustaka.

Subawa, Nyoman Sri. (2015). "Geliat Hedonisme Era Postmodern" (dalam Ragam Wacana: Bahasa, Sastra, dan Budaya), Editor: Erfiani,
Ni Made Diana. Yogyakarta: Pustaka Pelajar. Halaman 901-912

Tjiptono, Fandy. (2008). Strategi Pemasaran. Penerbit CV. ANDI OFFSET. Edisi III. Yogyakarta.

Wagner, Bernhard \& McLaughlin, Kenneth, (2015). "Politicizing the Psychology of Social Class: The Relevance of Pierre Bourdieu's Habitus for Psychological Research". Sage Journals. Page 147-166. Retrieved: http://tap. sagepub.com 